\title{
Mass screening of Trichoderma spp. for their antagonism against some plant pathogenic oomycetes fungi
}

\author{
Erayya* \\ Department of Plant Pathology, G.B. Pant University of Agriculture \& Technology , Pant- \\ nagar-263145, (Uttarakhand), India \\ Nandani Shukla \\ Department of Plant Pathology, G.B. Pant University of Agriculture \& Technology , Pant- \\ nagar-263145, (Uttarakhand), India
}

Kahkashan Arzoo

Department of Plant Pathology, G.B. Pant University of Agriculture \& Technology , Pantnagar-263145, (Uttarakhand), India

J. Kumar

Department of Plant Pathology, G.B. Pant University of Agriculture \& Technology , Pantnagar-263145, (Uttarakhand), India

${ }^{*}$ Corresponding author. E-mail: erayyapath@gmail.com

\begin{abstract}
In vitro efficacy of twenty five Trichoderma isolates (twenty were TCMS series viz., TCMS $2,4,5,12,14 \mathrm{a}, 14 \mathrm{~b}, 15,16,24,32,34,36,43,60,62,64,65,72,85$ and 93 , and five Th series; Th 1, 3, 14, 19 and 32) were ascertained for their antagonistic activity against few major plant pathogenic oomycetes namely, Phytophthora infestans, $P$. parasitica and Pythium aphenidermatum using dual culture technique. $P$. infestans was isolated from infected potato leaves and Pythium aphenidermatum from infected brinjal. $P$. parasitica culture was collected from Central Potato Research Institute (CPRI), Simla. The present study was conducted at Biological Control Laboratory, Department of Plant Pathology, G.B. Pant University of Agriculture and Technology, Pantnagar. All the 25 Trichodrma isolates were found significantly effective against the test pathogens. TCMS-36 and TCMS-72 were found highly effective against $P$. aphinidermatum with 59.57 per cent inhibition of radial growth of the fungus. Maximum reduction in mycelial growth of $P$. infestans was recorded with isolate TCMS-64 (60.40\%) followed by TCMS-65 $(59.41 \%)$, TCMS-34 (58.42\%), TCMS-24, TCMS-43 and TCMS-93 with 57.43 per cent inhibition. While, maximum inhibition of $P$. parasitica was recorded with TCMS-4 $(92.75 \%)$ followed by TCMS36 (92.23\%), TCMS-2 (91.71\%), TCMS-14a (91.17\%) and TCMS-32 (90.67\%). The selected potential isolates may be applied to sustainable and eco-friendly management of many major crop diseases caused by the oomycetes and other fungi.
\end{abstract}

Keywords: Antagonism, Bioagent, Dual culture, Management, Oomycetes

\section{INTRODUCTION}

Several phyto-pathogenic oomycetes fungi, such as Phytopthora, Pythium, Peronospora, etc. have been causing enormous losses since many decades due to changes introduced in agriculture system which resulted in detrimental effects on economically important crops. Agrochemicals have been used to manage plant diseases in generally, but chemical control has so many drawbacks like resistance development, effects on non target organisms, environmental pollution, food poisoning etc. While, biological control is risk-free, eco-friendly, sustainable and self perpetuating. In general biocontrol agents interfere with the life cycle of pathogens.

Among the micro-organisms fungi are most commonly used as biological control agents to

\section{Article Info}

DOI:10.31018/jans.v10i3.1718

Received: April 29, 2018

Revised: May 28, 2018

Accepted: June 10, 2018

\section{How to Cite}

Erayya, et al. (2018).

Mass Screening of Trichoderma spp. for their Antagonism against some Plant Pathogenic Oomycetes Fungi. Journal of Applied and Natural Science, 10 (3): 813-817 
site of the Appressorium attachment on the target fungus and directs the entry of Trichoderma spp. into the lumen of the pathogenicfungus (Rey et al., 2001; Freeman et al., 2002). Trichoderma spp. has different infection patterns including extracellular enzyme production. Diffusion of enzymes in-turn stimulates the target fungus to release cell-wall oligomers, and such oligomers enhance the production of endochitinases from the Trichoderma spp. which are toxic to the target fungus (Viterbo et al., 2002; Brunner et al., 2003). The cell wall degrading enzymes from Trichoderma includes $\beta-1,3$-glucanase, $\beta-1,6$ glucanases, proteases, hydrolases, cellulases etc. (Benitez et al., 1998). The combined effect of different enzyme, antibiosis and mycoparasitism results in dissolution of the cell wall of target fungus (Mendoza-Mendoza et al., 2003). Competition is another general mechanism of biological control. Competition exhibits between bioagent and plant pathogen for water, nutrients, vitamins and space for their growth (Cook and Baker, 1983; Muslim et al., 2003). Trichoderma spp. are irradiated with ultraviolet light to produce mutants which lacks antibiotic production and mycoparsitism ability (Howell, 2002). Competition at different rhizosphere varies depending on the availability of carbon, nitrogen, sulphur, phosphorus and other nutrient sources (Benitez et al., 2004).

Hence, the present experiment was ascertained on mass screening of Trichoderma spp. for their antagonism against some plant pathogenic oomycetes fungi in order to screen out the efficient strains of Trichoderma as a sustainable alternative method to manage crop diseases caused by the oomycetes.

\section{MATERIALS AND METHODS}

Phytophthora infestans and Pythium aphenidermatum were isolated from infected potato and brinjal, respectively. Phytophthora parasitica isolate was collected from Central Potato Research Institute (CPRI), Simla. P. aphenidermatum and $P$. parasitica cultures were grown on potato dextrose agar (PDA) medium at $26 \pm 1^{\circ} \mathrm{C}$ while $P$. infestans was cultured at $16 \pm 1^{\circ} \mathrm{C}$. The cultures were preserved at $4^{0} \mathrm{C}$ in a refrigerator. For isolation of Trichoderma spp. Soil samples were collected from copper mining sites/areas of Uttarakhand (Hence, the isolates were named as TCMS series) and the fungus was isolated on Trichoderma Specific Medium (TSM) using serial dilution and pour plate techniques.

Twenty five Trichoderma isolates (twenty TCMS series; TCMS 2, 4, 5, 12, 14a, 14b, 15, 16, 24, 32, $34,36,43,60,62,64,65,72,85,93$, and five Th series; Th 1, 3, 14, 19; 32) were ascertained for their antagonistic potential against $P$. infestans, $P$. aphenidermatum and $P$. parasitica by using dual culture plate technique. The studies were performed in Petri dishes poured with $20 \mathrm{ml}$ PDA. After solidification of medium, a $5.0 \mathrm{~mm}$ disc of the pathogen was cut from the edge of an actively growing culture, using a sterile cork borer, and inoculated in the Petri dish about $1.5 \mathrm{~cm}$ apart from the edge. Another $5.0 \mathrm{~mm}$ disc of a Trichoderma spp. was inoculated at the opposite end in the Petri dish at $1.5 \mathrm{~cm}$ from the edge. The experiment was carried out in three replications. The Petri dishes were incubated at $26 \pm 1^{\circ} \mathrm{C}$ while for $P$. infestans it was incubated at $16 \pm 1^{\circ} \mathrm{C}$. Observations on the growth of bio-control agent and test fungi were recorded after 72 hours of inoculation. Per cent inhibition of radial growth of test pathogen was calculated by applying the formula:

$$
I(\%)=\frac{(C-T)}{C} \times 100
$$

Where,

$\mathrm{I}=$ Per cent inhibition of radial growth of test fungus (pathogen)

$C=$ Radial growth of test fungus in control plate (without Trichoderma spp.)

$\mathrm{T}=$ Radial growth of test fungus in dual culture plate

\section{RESULTS AND DISCUSSION}

Antagonistic potential of 25 Trichoderma isolates was carried out against three oomycetes fungi under in votro conditions. Most of the Trichoderma spp. tested ware found significantly effective on inhibiting the radial growth of target pathogen/s.

Treatments were significantly differed from check and one another in inhibiting the radial growth of $P$. aphinidermatum. TCMS-36 and TCMS-72 were found highly effective against $P$. aphinidermatum. While, Th-14 was found least effective with $31.9 \%$ inhibition of radial growth followed by TCMS-62 with $34.04 \%$ inhibition (Table 1, Fig 1 and Plate 1). Efficacy of Trichoderma spp. against $P$. infestans was in the range of 36.67 to 60.40 per cent. Maximum reduction in hyphal growth was recorded with isolate TCMS-64 (60.40\%) followed by TCMS -65 (59.41\%), TCMS-34 (58.42\%), TCMS-24 $(57.43 \%)$, TCMS-43 $(57.43 \%)$ and TCMS-93 $(57.43 \%)$ (Table 1, Fig 1 and Plate 2). Per cent inhibition of hyphal growth of $P$. parasitica by Trichoderma spp. after $72 \mathrm{hr}$ was ranged from 54.92 to 92.75 per cent. Maximum inhibition was recorded with TCMS-4 $(92.75 \%)$ followed by TCMS-36 (92.23\%), TCMS-2 (91.71\%), TCMS14a $(19.17 \%)$ and TCMS-32 (90.67\%) while minimum inhibition in hyphal growth of $P$. parasitica was noticed with TCMS-34 (54.92\%), TCMS-72 (60.62\%), Th-32 (61.66\%) and Th-3 (62.18\%) (Table 1, Fig 1 and Plate 3). However the efficacy of tested Trichoderma spp. against $P$. parasitica under laboratory conditions was above 50 per 
Erayya, et al. / J. Appl. \& Nat. Sci. 10 (3): 813 - 817 (2018)

Table 1. Antagonism of Trichoderma spp. against some oomycetes.

\begin{tabular}{|c|c|c|c|c|c|c|c|}
\hline \multirow{2}{*}{$\begin{array}{l}\text { Sl. } \\
\text { No. }\end{array}$} & \multirow{2}{*}{$\begin{array}{l}\text { Trichoderma } \\
\text { Isolate }\end{array}$} & \multicolumn{2}{|c|}{ Pythium spp. } & \multicolumn{2}{|c|}{ P. infestans } & \multicolumn{2}{|c|}{ P.parasitica } \\
\hline & & $\begin{array}{l}\text { Radial } \\
\text { growth (cm) }\end{array}$ & $\begin{array}{l}\text { Inhibition } \\
(\%)\end{array}$ & $\begin{array}{l}\text { Radial } \\
\text { growth (cm) }\end{array}$ & $\begin{array}{l}\text { Inhibition } \\
(\%)\end{array}$ & $\begin{array}{l}\text { Radial } \\
\text { growth (cm) }\end{array}$ & $\begin{array}{l}\text { Inhibition } \\
(\%)\end{array}$ \\
\hline 1 & TCMS 2 & 0.77 & 51.06 & 2.03 & 39.60 & 0.53 & 91.71 \\
\hline 2 & TCMS 4 & 0.93 & 40.43 & 1.57 & 53.47 & 0.47 & 92.75 \\
\hline 3 & TCMS 5 & 0.80 & 48.94 & 2.27 & 32.67 & 2.20 & 65.80 \\
\hline 4 & TCMS 12 & 0.73 & 53.19 & 2.00 & 40.59 & 2.00 & 68.91 \\
\hline 5 & TCMS 14a & 0.70 & 55.32 & 1.70 & 49.50 & 0.57 & 91.19 \\
\hline 6 & TCMS $14 \mathrm{~b}$ & 0.70 & 55.32 & 1.73 & 48.51 & 1.47 & 77.20 \\
\hline 7 & TCMS 15 & 0.73 & 53.19 & 2.13 & 36.63 & 1.07 & 83.42 \\
\hline 8 & TCMS 16 & 0.70 & 55.32 & 1.63 & 51.49 & 0.87 & 86.53 \\
\hline 9 & TCMS 24 & 0.77 & 51.06 & 1.43 & 57.43 & 2.27 & 64.77 \\
\hline 10 & TCMS 32 & 0.80 & 48.94 & 1.77 & 47.52 & 0.60 & 90.67 \\
\hline 11 & TCMS 34 & 0.77 & 51.06 & 1.40 & 58.42 & 2.90 & 54.92 \\
\hline 12 & TCMS 36 & 0.63 & 59.57 & 1.47 & 56.44 & 0.50 & 92.23 \\
\hline 13 & TCMS 43 & 1.03 & 34.04 & 1.43 & 57.43 & 1.83 & 71.50 \\
\hline 14 & TCMS 60 & 0.67 & 57.45 & 1.60 & 52.48 & 1.00 & 84.46 \\
\hline 15 & TCMS 62 & 1.03 & 34.04 & 2.17 & 35.64 & 0.70 & 89.12 \\
\hline 16 & TCMS 64 & 0.67 & 57.45 & 1.33 & 60.40 & 1.47 & 77.20 \\
\hline 17 & TCMS 65 & 0.70 & 55.32 & 1.37 & 59.41 & 0.93 & 85.49 \\
\hline 18 & TCMS 72 & 0.63 & 59.57 & 1.73 & 48.51 & 2.53 & 60.62 \\
\hline 19 & TCMS 85 & 0.87 & 44.68 & 1.67 & 50.50 & 2.30 & 64.25 \\
\hline 20 & TCMS 93 & 0.73 & 53.19 & 1.43 & 57.43 & 0.83 & 87.05 \\
\hline 21 & Th 1 & 0.80 & 48.94 & 1.67 & 50.50 & 1.43 & 77.72 \\
\hline 22 & Th 3 & 0.78 & 50.43 & 1.97 & 41.58 & 2.43 & 62.18 \\
\hline 23 & Th 14 & 1.07 & 31.91 & 1.53 & 54.46 & 1.13 & 82.38 \\
\hline 24 & Th 19 & 0.87 & 44.68 & 1.80 & 46.53 & 1.77 & 72.54 \\
\hline 25 & Th 32 & 0.73 & 53.19 & 1.53 & 54.46 & 2.47 & 61.66 \\
\hline 26 & Control & 1.57 & 0.00 & 3.37 & 0.00 & 6.43 & 0.00 \\
\hline \multicolumn{2}{|c|}{ SEm \pm} & 0.32 & & 0.44 & & 0.36 & \\
\hline \multicolumn{2}{|c|}{ CD (0.01) } & 0.12 & & 0.17 & & 0.14 & \\
\hline
\end{tabular}

cent. Isolates TCMS-16, 24, 34, 36, 60, 64, 65, 93 and Th-32 were found significantly effective against all the test fungi $(P$. parasitica, $P$.infestans and $P$. aphinidermatum) with inhibition of mare than fifty per cent of mycelial growth of the pathogen.

Similar results were reported by the previous workers on the efficacy of Trichoderma spp. on many soil borne fungi. T. harzianum, and T. poly- sporum reduced the mycelial growth of $R$. solani under laboratory conditions varied from 59.6 to $78.4 \%$ (El-Kafrawy, 2002). Trichoderma species were found highly effective on Sclerotinia sclerotiorum, with $T$. atroviride the best in reducing fungal growth by $85-93 \%$ (Matroudi et al., 2009). Sixty two Trichoderma isolates were evaluated for their antagonism against soil-borne plant pathogens. Most of the tested Trichoderma spp. found highly

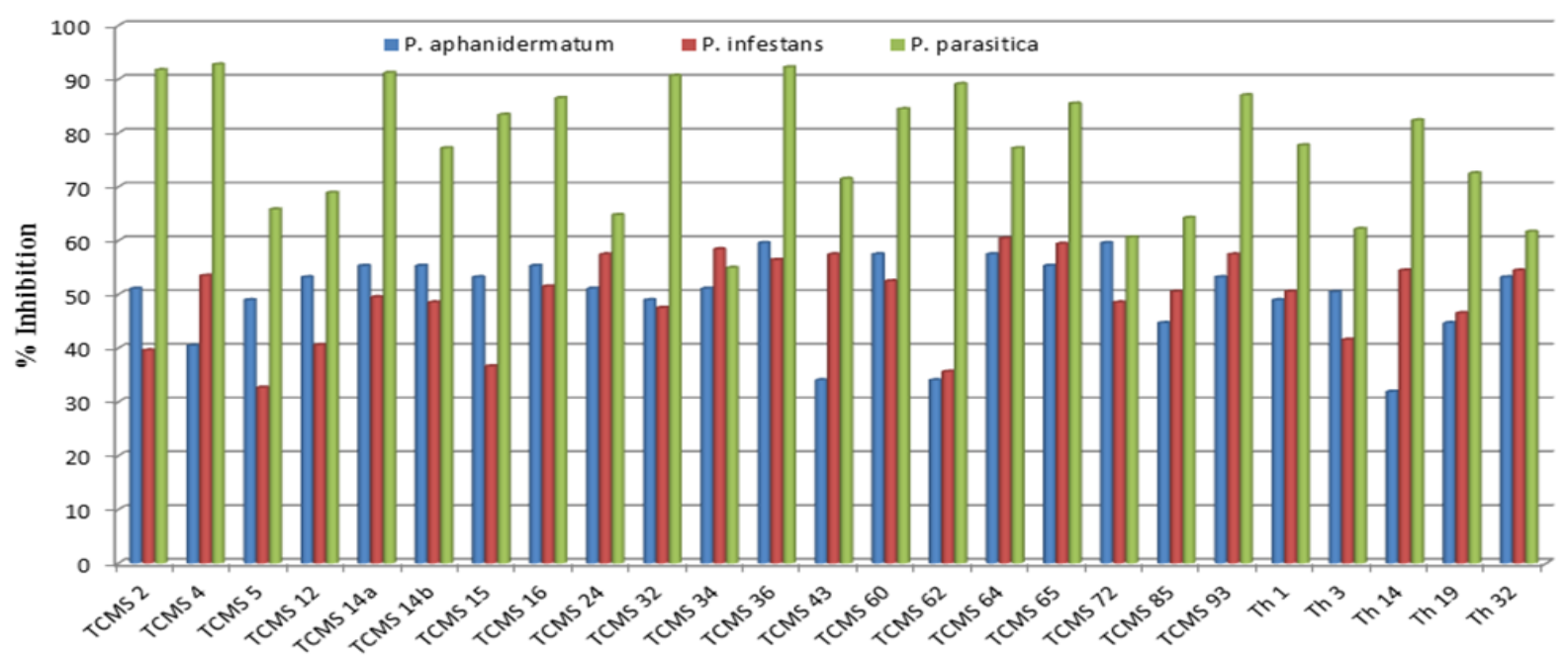

Trichoderma isolates

Fig. 1. Efficacy of Trichoderma isolates against some Oomycetes fungi. 
Erayya, et al. / J. Appl. \& Nat. Sci. 10 (3): 813 - 817 (2018)

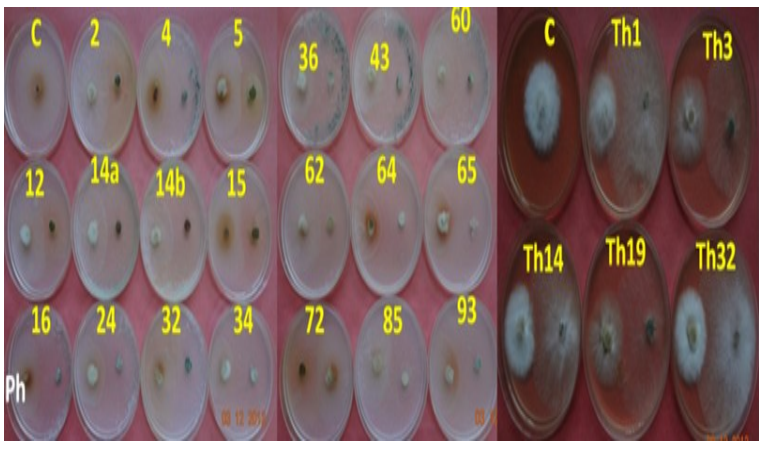

Plate 1. Antagonism of Trichoderma isolates on Pythium aphanidermatum.

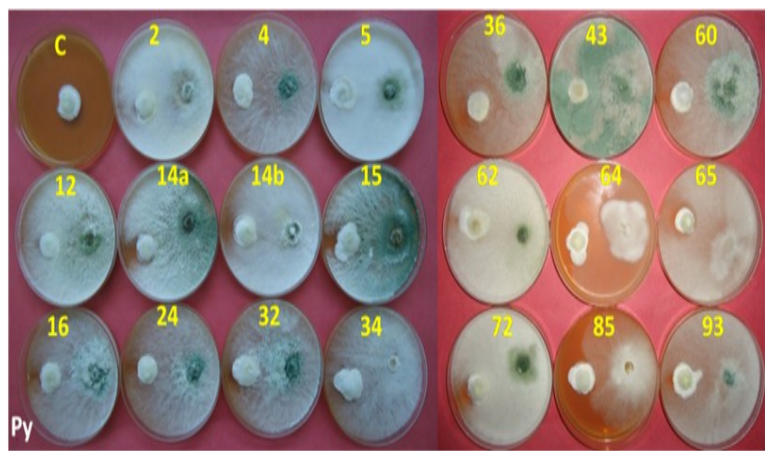

Plate 2. Antagonism of Trichoderma isolates on Phytophthora infestans.

significant in inhibiting the growth of the test pathogens (Joshi et al., 2010). Five per cent isolates were found efficient against $S$. rolfsii and $13 \%$ against $R$. solani, showed above $80 \%$ inhibition of mycelial growth. The antagonistic potential of five biocontrol fungi viz., $T$. harzianum, $B$. subtilis, $S$. noursei, G. roseum, and $S$. natalensis, was evaluated under in vitro against $C$. Gloeosporioides and C. acutatum (Svetlana et al., 2010). The antagonistic fungi inhibited vegetative growth and germination of conidia of Colletotrichum spp. Eighteen Trichoderma isolates showed considerable biocontrol potential while, $T$. atroviride was found best (Poornima Sharma, 2011). Antagonist of Trichoderma harzianum on $P$. aphanidermatum was more aggressive than $T$. viride. Per cent inhibition among $T$. harzianum isolates was varied only between 80 to $86 \%$ (Muthu Kumar and Pratibha Sharma, 2011). Many isolates of Trichoderma viride, were screened for their antagonism against several fungal plant pathogens. Among the tested isolates, $\operatorname{Tr} 8$ showed $70,68.2,70,73.3,69.3$ and 70.1 per cent inhibition of $R$. solani, S. rolfsii, $M$. phaseolina, A. alternata, F. solani and C. Capsici, respectively (Mishra et al., 2011). The inhibitory effect of Trichoderma spp. may mainly due to cellulolytic activity, antibiosis, mycoparasitism and competition for nutrients and space.

\section{Conclusion}

There was a significant difference in antagonism among the tested Trichoderama spp. against the

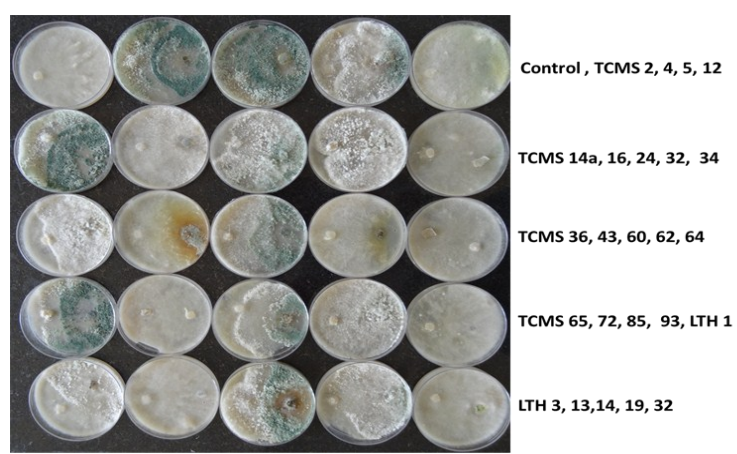

Plate 3. Antagonism of Trichoderma isolates on Phytophthora parasitica.

different oomycetes pathogens. Some isolates were found good against all the test pathogens. The range of inhibition by the same set of isolates also varied against Pythium and Phytophthora species. However, few isolates found most affective against all the test pathogens viz., $P$. aphanidermatum, $P$. infestens and $P$. parasitica. The selected potential candidates could be further screened in field conditions and can be effectively utilized to manage many plant diseases caused by oomycetes and other fungi (ascomycetes and basidiomycetes) in eco-friendly and sustainable manner.

\section{REFERENCES}

1. Benitez, T., Limon, J., Delgado Jarana, J. and Rey, M. (1998). Glucanolytic and other enzymes and their control. In: Trichoderma and Gliocladium, Vol. 2. G.E. Harman and C.P. Kubicek, eds. Taylor and Francis, London. pp. 101-127.

2. Benitez, T., Rincón, A.M., Limón, M.C. and Codón A.C. (2004). Biocontrol mechanisms of Trichoderma strains, Int. Microbiol. 7: 249-260.

3. Brunner, K., Peterbauer, C.K., Mach, R.L., Lorito, M., Zeilinger, S. and Kubicek, C.P. (2003). The Nag1 Nacetylglucosaminidase of Trichoderma atroviride is essential for chitnase induction by chitin and of major relevance to biocontrol. Curr. Genet. 43: 289-295.

4. Chaube, H.S., Mishra, D.S., Varshney, S. and Singh, U.S. (2002). Biological control of plant pathogens by fungal antagonists: Historical background, present status and future prospects. Annu. Rev. Plant Pathol. 2: $1-42$.

5. Chet, I., Harman, G.E. and Baker, R. (1981). Trichoderma harzianum. its hyphal interactions with Rhizoctonia solani and Pythium spp. Microb. Ecol. 7: 29-38.

6. Cook, R.J. and Baker, K.F. (1983). The Nature and Practice of Biological Control of Plant Pathogens. The American Phyto-pathological Society. St. Paul. Minnesota. pp. 539.

7. El-Kafrawy, A. A. (2002). Biological control of bean damping-off caused by Rhizoctonia solani. Egyptian Journal Agricultural Research 80 (1): 57-70.

8. Freeman, S., Maymon, M., Kirshner, B., Rav, D. and Elad, Y. (2002). Use of GUS transformants of Trichoderma harzianum isolate T39 (TRICHODEX) for studying interactions on leaf surfaces. Biocontrol Sci. Tech. 12 (3): 401-407.

9. Howell, C.R. (2002). Cotton seedling pre-emergence 
damping-off incited by Rhizopus oryzae and Pythium spp. and its biological control with Trichoderma spp. Phytopathology 92: 177-180.

10.Inbar, J., Menendez, A. and Chet, I. (1996). Hyphal interaction between Trichoderma harzianum and Sclerotinia sclerotiorum and its role in biological control. Soil Bio.Biochem. 28 (6): 757-763.

11.Joshi, B.B., Bhatt, R.P. and Bahukhandi, D. (2010). Antagonistic and plant growth activity of Trichoderma isolates of Western Himalayas Journal of Environmental Biology 31(6): 921-928.

12.Matroudi, S., Zamani, M.R and Motallebi, M. (2009). Antagonistic effects of three species of Trichoderma $\mathrm{sp}$. on Sclerotinia sclerotiorum, the causal agent of canola stem rot. Egyptian Journal of Biology, 11:37-44

13.Mendoza-Mendoza, A., Pozo, M.J., Grzegorski, D., Martinez, P., Garcia, J.M., Olmedo-Monfil, V., Cortés, C., Kenerley, C., and Herrera-Estrella, A. (2003). Enhanced biocontrol activity of Trichoderma through inactivation of a mitogen-activated protein kinase. Proceedings of the National Acacemy of Sciences of the United States of America 100: 15965-15970.

14.Mishra, B.K., Rohit, Kumar Mishra.. Mishra, R.C. Amit Kumar, Tiwari, Ramesh Singh, Yadav and Anupam Dikshit. (2011). Biocontrol efficacy of Trichoderma viride isolates against fungal plant pathogens causing disease in Vigna radiata L. Archives of Applied Science Research 3 (2): 361-369.

15.Mukhopadhyay, A.N. and Mukjerjee, P.K. (1998). Biological control of plant diseases: Status in India. In: Biological suppression of phytopathogens, Nematodes and Weeds (Singh, S. P. and Husain, S. S., eds.). Project Directorate of Biological Control, Ban- galore.

16.Muslim, A. Horinouchi, H. and Hyakumachi, M. (2003). Biological control of Fusarium wilt of tomato with hypovirulent binucleate Rhizoctonia in greenhouse conditions. Mycosci. 44:77-84.

17. Muthu Kumar, A. and Pratibha Sharma. (2011). Molecular and morphological characters: Anappurtenance for antagonism in Trichoderma spp. African Journal of Biotechnology 10(22): 4532-4543.

18.Poornima Sharma (2011). Complexity of Trichoderma-Fusarium interaction and manifestation of biological control. AJCS. 5(8): 1027-1038.

19.Rey, M., Delgado-Jarana, J. and Benitez, T. (2001). Improved antifungal activity of a mutant of Trichoderma harzianum CECT 2413 which produces more extracellular proteins. Appl. Microbio.Biotech. 55 (5): 604-608.

20.Singh, U.S., Mishra, D.S., Prasad, R.D., and Chaube, H.S. (2001a). Biological Control of Plant Pathogens in India: Historical perspectives, present status and future prospects. In: Hundred Years of Biological in India (ed., S. P. Singh), ICAR, New Delhi 21.Svetlana, Z., Stojanović1, S., Ivanović, Ž., Gavrilović, V., Tatjana, P. and jelica, B. (2010). Screening of antagonistic activity of microorganisms against Colletotrichum acutatum and Colletotrichum gloeosporioides.Arch. Biol. Sci., Belgrade 62 (3): 611-623.

22.Viterbo, A., Ramot, O., Chernin, L. and Chet, I. (2002). Significance of lytic enzymes from Trichoderma spp. in the biocontrol of fungal plant pathogens. Anton. Leeuw. 81:549-556.

23.Weindling, R. (1932). Trichoderma lignorum as a parasite of other soil fungi. Phytopathology 22: 834845. 